\title{
Role of ivermectin in patients hospitalized with COVID-19: a systematic review of literature
}

\begin{abstract}
The severe acute respiratory syndrome coronavirus 2 (SARS-CoV-2) has affected almost every country in the world since December 2019. Despite the efforts of the human race to combat the virus, we are still looking for an evidence-based permanent cure for the disease. Ivermectin has recently emerged as one of the therapies having a beneficial effect on COVID-19. Ivermectin, owing to its properties, continues to be a possible treatment against the COVID-19 disease. Already being a mainstream drug with minimal adverse effects, it garners valid consideration. It's use in hospitalized patients, randomized controlled trials, and observational studies has also supported its implementation. In this article, we have reviewed recent studies and explored the effectiveness of ivermectin in hospitalized COVID-19 patients.
\end{abstract}

Key words: ivermectin, COVID-19, SARS-CoV-2, virus, treatment, therapy

Adv Respir Med. 2021; 89: 413-418

\section{Introduction}

SARS-CoV-2 is a single-stranded RNA virus from the Coronaviridae family. There are 7 known species of the coronavirus that have the ability to infect humans. Its predecessor, SARS-CoV-1, can also cause severe respiratory disease. It comes as no surprise that, with little risk involved, there was not enough research done on SARS viruses which meant that we had to face a pandemic without much information about the causative agent. As of 21 February 2021, over 110 million people have been infected by the virus and about 2.4 million have lost their lives [1]. COVID-19 has also had a significant impact on the economic state of the whole world accounting for huge losses and unemployment. With so much going on, there has been immense pressure to find a suitable treatment for the disease. As such, interferon, hydroxychloroquine, chloroquine, conventional anti-virals, monoclonal antibodies, convalescent plasma therapy, and tocilizumab have been suggested as possible therapeutic options. However, studies have shown non-conclusive or insignificant evidence when it comes to patient mortality and other outcomes like disease progression, time to clinical stability, need of invasive ventilation, and duration of hospital stay [2-7]. This leaves the door open for debates on the efficacy of these drugs and whether clinicians should consider using them. So far, only corticosteroids have shown consistent encouraging signs towards a favorable prognosis of the disease [8].

Ivermectin has recently surfaced as one of the medicines showing promise in the therapy of COVID-19. They belong to the class of anti-parasitics called avermectins. First discovered in the 1970s, it has been recognized as a 'wonder drug' and its discovery earned a Nobel Prize for Physiology or Medicine in 2015 [9]. Since then, the drug has been used against a wide range of parasitic diseases like onchocerciasis, strongyloidiasis, and ascariasis both in humans and animals. It is currently FDA-approved and continues to be sold across the globe. It may be used orally or applied topically depending on the infection site. 


\section{Mechanism of action}

Ivermectin primarily amplifies the activity of GABA receptors or glutamate-gated chloride ion channels which leads to the inhibition of paralysis of somatic muscles via inhibition of myosin chain phosphorylation [10]. It is the blood-brain barrier (BBB) in vertebrates that protects them from the harmful effects of the drug in the central nervous system (CNS). Invertebrates, in contrast, are vulnerable to the actions of the drug due to a lack of the BBB. The fascinating part about ivermectin is its ability to affect a broad-range of diseases - it has shown anti-microbial, anti-cancer [11], and anti-viral properties.

The anti-viral properties of ivermectin mainly stem from its capacity to hinder the transport of viral proteins into the host nucleus via inhibition of the importin (IMP) $\alpha / \beta$ receptor. This allows it to inhibit the replication processes in various RNA and DNA viruses (e.g. Influenza, Zika Virus, Dengue Virus, Porcine circovirus, and others) [12, 13]. Indeed, in-vitro models support the theory that in SARS-CoV-2 a similar inhibitory effect leading to decreased replication will be seen [14]. Computer simulations claim that ivermectin might also bind to the $S$ protein of the virus or to ACE-2 in humans thereby warding of host cells from COVID-19 [15]. Another possible means by which ivermectin mediates its anti-viral properties is via allosteric modulation of the $\mathrm{P} 2 \mathrm{X} 4$ receptor, which leads to the secretion of CCL-5 using ATP [16]. Some studies suggest that ivermectin might have immunosuppressive effects $[17,18]$. This is particularly important since it may point to the possibility of ivermectin playing a complementary role of mitigating the inflammatory response during severe acute respiratory syndrome. As a matter of fact, evidence supports the use of ivermectin as an anti-Inflammatory drug in the treatment of existing diseases like Rosacea [19]. The results were quite optimistic in animal models as well [20].

The aim of this review is to provide a synopsis of the literature on the interaction between COVID-19 and ivermectin while trying to gauge the potential use of the drug against this devastating disease.

\section{Materials and methods}

We searched peer-reviewed databases such as PubMed and reviewed pre-print articles. We chose randomized controlled trials (RCTs) and observational studies in the English language that evaluated the effectiveness of ivermectin on
COVID-19 patients compared against standard treatment protocol, placebo, or other prospective medications in their study. Our review includes studies that were done on PCR-confirmed hospitalized COVID-19 patients. Factors such as dosage, timing, frequency, control group exposure, or publication status were not considered as appropriate filters.

The outcomes taken into consideration include:

1. Patient Mortality

2. C-Reactive Protein level

3. Time to discharge from the hospital

4. Viral load/clearance

Data extraction was carried out by the 2 reviewers independently. Articles were excluded if they were commentaries or opinion pieces. Studies examining the prophylactic effects of ivermectin in SARS-CoV-2 were also excluded. Duplicate articles, if any, were removed with the help of Mendeley software. Citations and data were included when considered appropriate. Any disagreement between the two reviewers was settled by a third, independent reviewer.

\section{Results}

After going through the databases, 14 studies were included in this review. Out of these, 8 were randomized controlled trials and 6 were observational studies. Of these 14 studies, 6 studies were peer-reviewed while 8 were preprints. A cumulative total of 7,744 laboratory-confirmed COVID-19 patients were involved - with 1,330 patients being a part of the ivermectin exposed group.

Patient mortality was reported in 8 studies which included a total of 6,770 patients. Out of these 6,770 patients, mortality was seen in $17.57 \%$ ( $n=1,190$ ) of patients, of which 82 were from the ivermectin exposed group. Only two studies did not classify patients according to severity of disease (Babalola et al. [21] and Soto-Beccerra et al. [22]). The rest of the trials included mild, moderate, and severely ill COVID-19 patients. A majority of subjects had comorbidities such as diabetes mellitus, hypertension, or various pulmonary diseases.

Table 1 describes the details of these studies in terms of design, dosage, size, and outcomes.

Administration and dosage of ivermectin varied across all studies. The lowest dosage used was $0.2 \mathrm{mg} / \mathrm{kg}$, whereas the highest was $0.4 \mathrm{mg} / \mathrm{kg}$. The most frequent dosage used, however, was $0.2 \mathrm{mg} / \mathrm{kg}$. In some cases, absolute values such as 
Table 1. Sample size and characteristics of the selected studies

\begin{tabular}{|c|c|c|c|c|c|}
\hline $\begin{array}{l}\text { Study name } \\
\text { and design }\end{array}$ & Size & $\begin{array}{c}\text { Intervention } \\
\text { (dosage, frequency, duration) }\end{array}$ & Control & $\begin{array}{l}\text { All-cause } \\
\text { mortality }\end{array}$ & $\begin{array}{l}\text { Other notable } \\
\text { outcomes }\end{array}$ \\
\hline $\begin{array}{l}\text { Elgazzar et al. [23] } \\
\text { RCT }\end{array}$ & $n=400$ & $\begin{array}{l}0.4 \mathrm{mg} / \mathrm{kg} \text { IVM }+\mathrm{ST} \\
\text { Once daily for } 4 \text { days }\end{array}$ & $\mathrm{HCO}+\mathrm{ST}$ & $1 \%$ vs $12 \%$ & $\begin{array}{l}\text { Reduced CRP levels } \\
(90 \% \text { and } 56 \% \text { vs } 84 \% \\
\text { and } 14 \%) \\
\text { and hospital stay }\end{array}$ \\
\hline $\begin{array}{l}\text { Niaee et al. [24] } \\
\text { RCT }\end{array}$ & $n=180$ & $\begin{array}{c}0.2-0.4 \mathrm{mg} / \mathrm{kg} \text { IVM } \\
\text { Once daily or on } 3 \text { interval days }\end{array}$ & $\begin{array}{c}\text { ST or } \\
\text { ST + Placebo }\end{array}$ & $3.3 \%$ vs $18.3 \%$ & $\begin{array}{l}\text { Reduced CRP levels, } \\
\text { DLO, hospital stay }\end{array}$ \\
\hline $\begin{array}{l}\text { Hashim et al. [25] } \\
\text { RCT }\end{array}$ & $\begin{array}{c}n=140 \\
(44 \mathrm{HP})\end{array}$ & $\begin{array}{l}0.2 \mathrm{mg} / \mathrm{kg} \text { IVM (once for } 2-3 \text { days) } \\
+ \text { DC (twice for } 5 \text { days) + ST }\end{array}$ & ST & $\begin{array}{l}0 \% \text { vs } 27.3 \% \\
\text { in severely ill HP }\end{array}$ & $\begin{array}{l}\text { Lower rate of progres- } \\
\text { sion ( } 9 \% \text { vs } 31.8 \%) \\
\text { and hospital stay } \\
\text { (avg. } 7 \text { days) }\end{array}$ \\
\hline $\begin{array}{l}\text { Kirti et al. [26] } \\
\text { RCT }\end{array}$ & $\mathrm{n}=112$ & $\begin{array}{l}12 \text { mg IVM (days } 1 \text { and 2) } \\
+ \text { ST (days 3-6) }\end{array}$ & $\begin{array}{l}\text { ST + Placebo } \\
6 \text { days }\end{array}$ & $0 \%$ vs $7 \%$ & $\begin{array}{l}\text { Did not seem to affect } \\
\text { negative RT-PCR } \\
(23.6 \% \text { vs } 31.6 \%)\end{array}$ \\
\hline $\begin{array}{l}\text { *Spoorthi et al. } \\
{[31]} \\
\text { RCT }\end{array}$ & $n=100$ & $\begin{array}{c}0.2 \mathrm{mg} / \mathrm{kg} \text { IVM once and } / \mathrm{or} \\
\text { DC }\end{array}$ & Placebo & $\mathrm{N} / \mathrm{A}$ & $\begin{array}{c}\text { Shorter clinical recovery } \\
\text { (3.7 vs } 4.7 \text { days) and } \\
\text { stay ( } 6.7 \text { vs } 7.9 \text { days) }\end{array}$ \\
\hline $\begin{array}{l}\text { Ahmed et al. [30] } \\
\text { RCT }\end{array}$ & $\mathrm{n}=72$ & $\begin{array}{c}12 \mathrm{mg} \text { IVM }+ \text { ST } \\
\text { Once daily for } 1 \text { or } 5 \text { day(s) }\end{array}$ & Placebo + ST & $\mathrm{N} / \mathrm{A}$ & $\begin{array}{l}\text { Faster viral clearance } \\
\text { (11.5 and } 9.7 \\
\text { vs } 12.7 \text { days) }\end{array}$ \\
\hline $\begin{array}{l}\text { Babalola et al. [21] } \\
\text { RCT }\end{array}$ & $\mathrm{n}=62$ & $\begin{array}{l}6 \mathrm{mg} \text { or } 12 \mathrm{mg} \text { IVM }+ \text { ST } \\
\text { Twice a week for } 2 \text { weeks }\end{array}$ & $\begin{array}{l}\mathrm{LPV} / \mathrm{r}+\mathrm{ST} \\
\text { Daily }\end{array}$ & $\mathrm{N} / \mathrm{A}$ & $\begin{array}{l}\text { Faster viral clearance } \\
\text { ( } 4.7 \text { and } 6 \text { vs } 9 \text { days) }\end{array}$ \\
\hline $\begin{array}{l}\text { Chachar et al. [32] } \\
\text { RCT }\end{array}$ & $n=50$ & $\begin{array}{l}12 \mathrm{mg} \text { IVM }+ \text { ST } \\
3 \text { doses in } 2 \text { days }\end{array}$ & ST & $\mathrm{N} / \mathrm{A}$ & $\begin{array}{l}\text { Difference in clinical } \\
\text { recovery did not reach } \\
\text { statistically significant } \\
\text { levels }\end{array}$ \\
\hline $\begin{array}{l}\text { Soto-Beccerra } \\
\text { et al. [22] } \\
\text { OBS }\end{array}$ & $\mathrm{n}=5683$ & $\begin{array}{c}\text { IVM } \\
\text { Within } 48 \text { hours }\end{array}$ & ST & $51.4 \%$ vs $42.6 \%$ & - \\
\hline $\begin{array}{l}{ }^{*} \text { Rahman et al. [34] } \\
\text { OBS }\end{array}$ & $n=400$ & $\begin{array}{l}18 \mathrm{mg} \mathrm{IVM} \mathrm{once}+100 \mathrm{mg} \mathrm{DC} \\
\text { twice daily for } 5 \text { days }\end{array}$ & $\mathrm{HCO}+\mathrm{AZIT}$ & $\mathrm{N} / \mathrm{A}$ & $\begin{array}{l}\text { Faster and better viral } \\
\text { clearance ( } 16.5 \% \text { on day } \\
6 \text { vs } 18.5 \% \text { on day } 12)\end{array}$ \\
\hline $\begin{array}{l}\text { *Rajter et al. [27] } \\
\text { OBS }\end{array}$ & $\mathrm{n}=280$ & $\begin{array}{l}0.2 \mathrm{mg} / \mathrm{kg} \text { IVM }+\mathrm{ST} \\
\text { Mostly once }\end{array}$ & $\begin{array}{l}\text { ST with } \\
\text { or without } \\
\text { HCQ/AZIT }\end{array}$ & $\begin{array}{c}15.0 \% \text { vs } 25.2 \% \\
(38.8 \% \text { vs } 80.7 \% \\
\text { in severe patients) }\end{array}$ & $\begin{array}{l}\text { No difference found in } \\
\text { the length of stay }\end{array}$ \\
\hline $\begin{array}{l}{ }^{*} \text { Khan et al. [28] } \\
\text { OBS }\end{array}$ & $\mathrm{n}=248$ & $\begin{array}{l}12 \mathrm{mg} \mathrm{IVM} \\
\text { Once }\end{array}$ & ST & $0.9 \%$ vs $6.8 \%$ & $\begin{array}{l}\text { Shorter recovery time } \\
\text { (9 days vs } 15 \text { days) } \\
\text { and faster viral clearance } \\
\text { (4 days vs } 15 \text { days) }\end{array}$ \\
\hline $\begin{array}{l}\text { *Gorial et al. [29] } \\
\text { OBS }\end{array}$ & $\mathrm{n}=87$ & $\begin{array}{c}0.2 \mathrm{mg} / \mathrm{kg} \mathrm{IVM}+\mathrm{HCO}+\mathrm{AZIT} \\
\text { Once }\end{array}$ & $\mathrm{HCO}+\mathrm{AZT}$ & $0 \%$ vs $2.8 \%$ & $\begin{array}{l}\text { Shorter duration of stay } \\
\text { (7.6 days vs } 13.2 \text { days) } \\
\text { and faster viral clearance } \\
\text { (7 days vs } 12 \text { days) }\end{array}$ \\
\hline $\begin{array}{l}{ }^{*} \text { Camprubi } \\
\text { et al. [33] } \\
\text { OBS }\end{array}$ & $\mathrm{n}=26$ & $\begin{array}{c}0.2 \mathrm{mg} / \mathrm{kg} \text { IVM }+ \text { IS } \\
\text { Once on the onset of symptoms }\end{array}$ & IS & $\mathrm{N} / \mathrm{A}$ & $\begin{array}{c}\text { Small differences in } \\
\text { discharges, need for ICU }\end{array}$ \\
\hline
\end{tabular}

${ }^{*}$ Studies with one dose of ivermectin.

AZIT — azithromycin; CRP — C-reactive protein; DC — doxycycline; DLO — duration of low $\mathrm{O}_{2}$ saturation; $\mathrm{HCO}$ - hydroxychloroquine; HP — hospitalized patients; IS —immunosuppressants; IVM — ivermectin; LPV/r — lopinavir/ritonavir; N/A — not applicable; OBS — observational study; RCT — randomized controlled trial; ST — standard therapy

6, 12, or $18 \mathrm{mg}$ were used. Differences in one day and multi-day dosing were also noted. Just over a third of trials exposed the clinical group to another medicine (excluding those in the standard of care) such as doxycycline, azithromycin, etc. Mortality was noted across eight different reports, and in almost all of them death occurrence was more prominent in the control arm [23-29]. The 
only study whose findings were not consistent with the rest is the retrospective cohort in Peru by Soto-Beccerra et al. [22] which found a higher mortality rate in the interventional group.

Viral clearance was recorded in 5 studies, all of which were able to show a reduced time required for viral clearance or viral load after a set time in the study group [21, 23, 28-30]. Perhaps the most pronounced effects were seen in the retrospective study by Khan et al. [28] in which the median time required for viral clearance decreased from 15 days to just 4 days.

Eight trials measured the duration of hospitalization as an outcome. Six out of these revealed a shorter stay in hospitals in the ivermectin arm compared to the control group [23-25, 28, 29, 31]. In two studies, the results did not reach statistical significance [27, 32].

Out of the studies, two did not show a significant decrease in C-reactive protein (CRP) levels compared to the control group [29, 33], whereas three highlighted a statistically significant decrease $[23,24,30]$. In a randomized multi-center trial conducted by Niaee et al. [24] with $\mathrm{p}<0.001$, reduced CRP levels across all arms were observed. Out of all 5, Elgazzar et al. [23] and Niaee et al. [24] were the only two studies with sample sizes of over 100 subjects.

Patterns may also suggest the existence of a dose-response relationship. In one of two studies, Ahmed et al. illustrated that taking ivermectin for 5 days instead of 1 day increased the rate of viral clearance [30]. Similarly, Babalola et al. [21] found that the arm exposed to $12 \mathrm{mg}$ ivermectin instead of $6 \mathrm{mg}$ had faster clearance by over 1 day. However, in one case, where 3 dosing strategies were utilized against a control of standard therapy and placebo, there were similar mortality rates and length of hospital stays across interventional arms [24].

We also noticed one-dose trials, such as the one conducted by Gorial et al. [29], which saw all members of the study group cured against $97.2 \%$ of the control group. Meanwhile, the dichotomy in mortality rates was more pronounced in most multi-day dose trials (as summarized in Table 1), supporting the above hypothesis. Statistically, insignificant findings in length of hospitalization $[27,33]$ were also noted in one-time exposure studies, whereas only one multi-exposure study yielded similarly insignificant results [32]. However, a few one-dose studies did show major changes in at least one of the 3 categories [27-29, $31,34]$, thereby resisting the theory of there being a relationship.

\section{Discussion}

This review suggests that ivermectin reduces mortality, CRP levels, and lengths of stay in the hospital while enhancing viral clearance in SARS-CoV-2 hospitalized patients in different populations around the world.

In the study carried out by Soto-Beccerra et al. [22], which pushes back against the notion of ivermectin decreasing mortality in COVID-19 patients, it should be noted that the same report found increased weighted hazard or unweighted hazard ratios in all interventional groups (others included azithromycin, hydroxychloroquine, or a combination of all 3 drugs). The data could be limited since zero deaths occurred on the second day in the control arm whereas mortality was reported in all other groups (deaths in the first 24 hours were not included for both arms).

These findings are also supported by a systematic review and meta-analysis performed by Padhy et al. [35]. However, it should be noticed that they used ivermectin as an adjuvant, only chose 4 observational studies, and included outpatient data. The studies chosen in this review are specific to hospitalized COVID-19 patients, larger in quantity, and include RCTs. A recent case series also supported these findings as 34 subjects treated with ivermectin all survived and mortality was observed in the other group(s) [36].

This is particularly encouraging keeping in view the current situation of the pandemic. The anti-viral activity of ivermectin seems to make it a very viable option for the treatment of such patients. The safety of this drug is well documented [37, 38]. A study that compiled data from other studies, including 50,000 subjects in Cameroon, found that only 20 faced serious complications [39]. Being relatively affordable and readily available makes it economically/logistically feasible.

However, we urge medical professionals to exercise prudence until more high-quality evidence is available. The COVID-19 Treatment Guidelines Panel at NIH stated on January 14, 2021 that there is 'insufficient data to recommend either for or against the use of ivermectin for the treatment of COVID-19' due to the fact that 'significant methodological limitations and incomplete information' were visible across trials [40]. In addition, Merck \& Co. (known as MSD outside USA and Canada), which originally marketed the drug, identified a lack of evidence on February 4, 2021 with regards to the use of ivermectin in COVID-19 [41]. In a recent randomized clinical trial in patients with mild COVID-19 treated 
with ivermectin, Lopez-Medina et al. [42] found no significant difference in time to resolution of symptoms in comparison with placebo. We too believe it is early to include ivermectin in existing protocols for similar reasons. There are other issues that may make ivermectin unsuitable. It is poor as far as water solubility is concerned, which is why it is not absorbed well via the oral route [43]. Nevertheless, it should be mentioned that liposomal and inhalational therapy might help tackle this issue. Although ivermectin is not able to cross the BBB, in patients with hyper-inflammation, a docile BBB may permit passage into the CNS. As a matter of fact, we ask that quantitative analyses and better designed high-powered RCTs be run on the efficacy of the drug.

In the case of the dose-response relationship mentioned above, there is insufficient data to conclude anything. The only thing we consistently saw across studies was a decrease in viral load at higher doses when directly compared to lower doses [21, 23]. Although some one-dose studies did show smaller changes when compared to their multi-dosage counterparts, others found significant results in a few outcomes. It should be noted that exclusive administration of ivermectin across most of the aforementioned studies was scarce. It is possible that the significant reduction in viral clearance by the drug does not necessarily translate into early discharge from the hospital or a decrease in all-cause mortality. However, we cannot merely surmise that. We encourage other researchers to investigate this question while exploring the drug and its potential as a therapeutic option for said population.

\section{Limitations}

Due to the current COVID-19 pandemic, the reviewers agreed to include pre-print data in the article, which is not peer-reviewed. Standard treatment regimens, dosage, duration, inclusion/exclusion criteria, and definition of severity of disease differed across all studies. Furthermore, in some trials, ivermectin was used in conjunction with either standard treatment or other drugs (azithromycin, doxycycline, etc.). Publication bias might exist in some studies.

\section{Conclusion}

Ivermectin, owing to its properties, continues to be a potential therapeutic option against the COVID-19 disease that we are facing. Already being a mainstream drug with minimal adverse effects, it garners valid consideration and atten- tion in these times. In hospitalized patients, RCTs and observational studies have supported its use. Still, there needs to be more high-quality proof and quantitative analysis in order to legitimize its use as part of general protocol. As for now, we shall have to wait for the final verdict on the capabilities of ivermectin.

\section{Conflict of interest}

None declared.

\section{References:}

1. World Health Organization. Weekly epidemiological update - 23 February 2021. https:/www.who.int/publications/m/ item/weekly-epidemiological-update---23-february-2021 (5.03.2021).

2. Hongchao P, Peto R, Henao-Restrepo AM, et al. Repurposed antiviral drugs for COVID-19: interim WHO solidarity trial results. N Engl J Med. 2021; 384(6): 497-511, doi: 10.1056/ NEJMoa2023184, indexed in Pubmed: 33264556.

3. Cai Q, Yang M, Liu D, et al. Experimental treatment with favipiravir for COVID-19: an open-label control study. Engineering (Beijing). 2020; 6(10): 1192-1198, doi: 10.1016/j. eng.2020.03.007, indexed in Pubmed: 32346491.

4. Hermine O, Mariette X, Tharaux PL, et al. CORIMUNO-19 Collaborative Group. Effect of tocilizumab vs usual care in adults hospitalized with COVID-19 and moderate or severe pneumonia: a randomized clinical trial. JAMA Intern Med. 2021; 181(1): 32-40, doi: 10.1001/jamainternmed.2020.6820, indexed in Pubmed: 33080017.

5. Agarwal A, Mukherjee A, Kumar G, et al. PLACID Trial Collaborators. Convalescent plasma in the management of moderate covid-19 in adults in India: open label phase II multicentre randomised controlled trial (PLACID Trial). BMJ. 2020; 371: m3939, doi: 10.1136/bmj.m3939, indexed in Pubmed: 33093056.

6. Gul MH, Htun ZM, Shaukat N, et al. Potential specific therapies in COVID-19. Ther Adv Respir Dis. 2020; 14: 1753466620926853, doi: 10.1177/1753466620926853, indexed in Pubmed: 32436445.

7. Tufan A, Avanoğlu Güler A, Matucci-Cerinic M. COVID-19, immune system response, hyperinflammation and repurposing antirheumatic drugs. Turk J Med Sci. 2020; 50(SI-1): 620-632, doi: 10.3906/sag-2004-168, indexed in Pubmed: 32299202.

8. Horby P, Lim WS, Emberson JR, et al. RECOVERY Collaborative Group. Dexamethasone in Hospitalized Patients with Covid-19. N Engl J Med. 2021; 384(8): 693-704, doi: 10.1056/ NEJMoa2021436, indexed in Pubmed: 32678530.

9. Crump A, Ōmura S. Ivermectin, ,wonder drug' from Japan: the human use perspective. Proc Jpn Acad Ser B Phys Biol Sci. 2011; 87(2): 13-28, doi: 10.2183/pjab.87.13, indexed in Pubmed: 21321478.

10. Martin RE, Donahue MJ. Correlation of myosin light chain phosphorylation and gamma aminobutyric acid receptors in Ascaris suum muscle. Comp Biochem Physiol C Comp Pharmacol Toxicol. 1987; 87(1): 23-29, doi: 10.1016/07428413(87)90174-5, indexed in Pubmed: 2885136.

11. Sharun K, Dhama K, Patel SK, et al. Ivermectin, a new candidate therapeutic against SARS-CoV-2/COVID-19. Ann Clin Microbiol Antimicrob. 2020; 19(1): 23, doi: 10.1186/s12941020-00368-w, indexed in Pubmed: 32473642.

12. Yang SNY, Atkinson SC, Wang C, et al. The broad spectrum antiviral ivermectin targets the host nuclear transport importin $\alpha /$ $\beta 1$ heterodimer. Antiviral Res. 2020; 177: 104760, doi: 10.1016/j. antiviral.2020.104760, indexed in Pubmed: 32135219.

13. Wang $\mathrm{X}, \mathrm{Lv} \mathrm{C}$, Ji $\mathrm{X}$, et al. Ivermectin treatment inhibits the replication of Porcine circovirus 2 (PCV2) in vitro and mitigates the impact of viral infection in piglets. Virus Res. 2019; 263: 80-86, doi: 10.1016/j.virusres.2019.01.010, indexed in Pubmed: 30658073. 
14. Caly L, Druce JD, Catton MG, et al. The FDA-approved drug ivermectin inhibits the replication of SARS-CoV-2 in vitro. Antiviral Res. 2020; 178: 104787, doi: 10.1016/j.antiviral.2020.104787, indexed in Pubmed: 32251768.

15. Abdel-Mottaleb M, Abdel-Mottaleb Y. In search for effective and safe drugs against sars-cov-2: part I] simulated interactions between selected nutraceuticals, ACE2 enzyme and s protein simple peptide sequences. ChemRxiv. 2020, doi: 10.26434/ chemrxiv.12155235.

16. Priel A, Silberberg SD. Mechanism of ivermectin facilitation of human P2X4 receptor channels. J Gen Physiol. 2004; 123(3): 281-293, doi: 10.1085/jgp.200308986, indexed in Pubmed: 14769846.

17. Njoo FL, Hack CE, Oosting J, et al. C-reactive protein and interleukin-6 are elevated in onchocerciasis patients after ivermectin treatment. J Infect Dis. 1994; 170(3): 663-668, doi: 10.1093/ infdis/170.3.663, indexed in Pubmed: 8077726.

18. Zhang X, Song Y, Ci X, et al. Ivermectin inhibits LPS-induced production of inflammatory cytokines and improves LPS-induced survival in mice. Inflamm Res. 2008; 57(11): 524-529, doi: 10.1007/s00011-008-8007-8, indexed in Pubmed: 19109745

19. Steinhoff M, Vocanson M, Voegel JJ, et al. Topical ivermectin $10 \mathrm{mg} / \mathrm{g}$ and oral doxycycline $40 \mathrm{mg}$ modified-release: current evidence on the complementary use of anti-inflammatory rosacea treatments. Adv Ther. 2016; 33(9): 1481-1501, doi: 10.1007/s12325-016-0380-z, indexed in Pubmed: 27432381.

20. de Melo GD, Lazarini F, Larrous F, et al. Anti-COVID-19 efficacy of ivermectin in the golden hamster. bioRxiv. 2020, doi: 10.1101/2020.11.21.392639.

21. Babalola OE, Bode CO, Ajayi AA, et al. Ivermectin shows clinical benefits in mild to moderate COVID19: A randomised controlled double-blind, dose-response study in Lagos. QJM. 2021 [Epub ahead of print]: hcab035, doi: 10.1093/qjmed/ hcab035, indexed in Pubmed: 33599247.

22. Soto-Becerra P, Culquichicón C, Hurtado-Roca Y, et al. Real-world effectiveness of hydroxychloroquine, azithromycin, and ivermectin among hospitalized COVID-19 patients: results of a target trial emulation using observational data from a nationwide healthcare system in Peru. medRxiv. 2020, doi: 10.1101/2020.10.06.20208066.

23. Elgazzar A, Hany B, Youssef S, et al. Efficacy and safety of ivermectin for treatment and prophylaxis of COVID-19 pandemic. Research Square. 2020, doi: 10.21203/rs.3.rs-100956/v2.

24. Niaee M, Gheibi N, Namdar P, et al. Ivermectin as an adjunct treatment for hospitalized adult COVID-19 patients: a randomized multi-center clinical trial. Research Square. 2020, doi: 10.21203/rs.3.rs-109670/v1.

25. Hashim H, Maulood M, Rasheed A, et al. Controlled randomized clinical trial on using Ivermectin with Doxycycline for treating COVID-19 patients in Baghdad, Iraq. medRxiv. 2020, doi: 10.1101/2020.10.26.20219345.

26. Roy R, Pattadar C, Raj R, et al. Evaluation of ivermectin as a potential treatment for mild to moderate COVID-19: a double-blind randomized placebo controlled trial in eastern india. J Pharm Pharm Sci. 2021; 24: 343-350, doi: 10.18433/ jpps32105, indexed in Pubmed: 34265236.

27. Rajter JC, Sherman MS, Fatteh N, et al. Use of ivermectin is associated with lower mortality in hospitalized patients with coronavirus disease 2019: the ivermectin in COVID nineteen study. Chest. 2021; 159(1): 85-92, doi: 10.1016/j. chest.2020.10.009, indexed in Pubmed: 33065103.

28. Khan SI, Khan SI, Debnath CR, et al. Ivermectin treatment may improve the prognosis of patients with COVID-19. Arch Bron- coneumol (Engl Ed). 2020; 56(12): 828-830, doi: 10.1016/j. arbres.2020.08.007, indexed in Pubmed: 33293006.

29. Gorial F, Mashhadani S, Sayaly H, et al. Effectiveness of ivermectin as add-on therapy in COVID-19 management (pilot trial). medRxiv. 2020, doi: 10.1101/2020.07.07.20145979.

30. Ahmed S, Karim MM, Ross AG, et al. A five-day course of ivermectin for the treatment of COVID-19 may reduce the duration of illness. Int J Infect Dis. 2021; 103: 214-216, doi: 10.1016/j. ijid.2020.11.191, indexed in Pubmed: 33278625.

31. Spoorthi V, Sasank S. Utility of ivermectin and doxycycline combination for the treatment of SARS-CoV2. Int Arch Integrated Med. 2020; 7(10): 177-182.

32. Chachar AZ, Khan KA, Asif M, et al. Effectiveness of ivermectin in SARS-CoV-2/COVID-19 patients. International Journal of Sciences. 2020; 9(09): 31-35, doi: 10.18483/ijsci.2378.

33. Camprubí D, Almuedo-Riera A, Martí-Soler H, et al. Lack of efficacy of standard doses of ivermectin in severe COVID-19 patients. PLoS One. 2020; 15(11): e0242184, doi: 10.1371/ journal.pone.0242184, indexed in Pubmed: 33175880.

34. Rahman M, Iqbal S, Islam M, et al. Comparison of viral clearance between ivermectin with doxycycline and hydroxychloroquine with azithromycin in COVID-19 patients. Journal of Bangladesh College of Physicians and Surgeons. 2020: 5-9, doi: 10.3329/jbcps.v38i0.47514.

35. Padhy BM, Mohanty RR, Das S, et al. Therapeutic potential of ivermectin as add on treatment in COVID 19: A systematic review and meta-analysis. J Pharm Pharm Sci. 2020; 23: 462469, doi: 10.18433/jpps31457, indexed in Pubmed: 33227231.

36. Budhiraja S, Soni A, Jha V, et al. Clinical profile of first 1000 COVID-19 cases admitted at tertiary care hospitals and the correlates of their mortality: an indian experience. medRxiv. 2020, doi: 10.1101/2020.11.16.20232223.

37. Guzzo CA, Furtek CI, Porras AG, et al. Safety, tolerability, and pharmacokinetics of escalating high doses of ivermectin in healthy adult subjects. J Clin Pharmacol. 2002; 42(10): 1122-1133, doi: 10.1177/009127002401382731, indexed in Pubmed: 12362927.

38. Kircik LH, Del Rosso JQ, Layton AM, et al. Over 25 years of clinical experience with ivermectin: an overview of safety for an increasing number of indications. J Drugs Dermatol. 2016; 15(3): 325-332, indexed in Pubmed: 26954318.

39. Gardon J, Gardon-Wendel N, Kamgno J, et al. Serious reactions after mass treatment of onchocerciasis with ivermectin in an area endemic for Loa loa infection. Lancet. 1997; 350(9070): 18-22, doi: 10.1016/s0140-6736(96)11094-1.

40. National Institutes of Health. The COVID-19 Treatment Guidelines Panel's Statement on the Use of Ivermectin for the Treatment of COVID-19 [Online]. NIH COVID-19 Treatment Guidelines. 2021 Jan 14. https://files.covid19treatmentguidelines. nih.gov/guidelines/section/section_106.pdf (5.03.2021).

41. Merck Statement on Ivermectin use During the COVID-19 Pandemic [Online]. 2021 Feb 4. http://www.merck.com/news/ merck-statement-on-ivermectin-use-during-the-covid-19-pandemic/ (5.03.2021)

42. López-Medina E, López P, Hurtado IC, et al. Effect of ivermectin on time to resolution of symptoms among adults with mild COVID-19: a randomized clinical trial. JAMA. 2021; 325(14): 1426-1435, doi: 10.1001/jama.2021.3071, indexed in Pubmed: 33662102 .

43. Takano R, Sugano K, Higashida A, et al. Oral absorption of poorly water-soluble drugs: computer simulation of fraction absorbed in humans from a miniscale dissolution test. Pharm Res. 2006; 23(6): 1144-1156, doi: 10.1007/s11095-006-0162-4, indexed in Pubmed: 16715363. 